\title{
Comparing chiral ferrocenyl and ruthenocenyl ligands: how subtle structural changes influence their performance in asymmetric catalysis
}

\section{Citation for published version (APA):}

Abbenhuis, H. C. L., Burckhardt, U., Gramlich, V., Martelletti, A. P., Spencer, J., Steiner, I., \& Togni, A. (1996). Comparing chiral ferrocenyl and ruthenocenyl ligands: how subtle structural changes influence their performance in asymmetric catalysis. Organometallics, 15(6), 1614-1621. https://doi.org/10.1021/om9508997

DOI:

10.1021/om9508997

Document status and date:

Published: 01/01/1996

\section{Document Version:}

Publisher's PDF, also known as Version of Record (includes final page, issue and volume numbers)

\section{Please check the document version of this publication:}

- A submitted manuscript is the version of the article upon submission and before peer-review. There can be important differences between the submitted version and the official published version of record. People interested in the research are advised to contact the author for the final version of the publication, or visit the DOI to the publisher's website.

- The final author version and the galley proof are versions of the publication after peer review.

- The final published version features the final layout of the paper including the volume, issue and page numbers.

Link to publication

\footnotetext{
General rights

- You may freely distribute the URL identifying the publication in the public portal. follow below link for the End User Agreement:

www.tue.nl/taverne

\section{Take down policy}

If you believe that this document breaches copyright please contact us at:

openaccess@tue.nl

providing details and we will investigate your claim.
}

Copyright and moral rights for the publications made accessible in the public portal are retained by the authors and/or other copyright owners and it is a condition of accessing publications that users recognise and abide by the legal requirements associated with these rights.

- Users may download and print one copy of any publication from the public portal for the purpose of private study or research.

- You may not further distribute the material or use it for any profit-making activity or commercial gain

If the publication is distributed under the terms of Article $25 \mathrm{fa}$ of the Dutch Copyright Act, indicated by the "Taverne" license above, please 


\title{
Comparing Chiral Ferrocenyl and Ruthenocenyl Ligands: How Subtle Structural Changes Influence Their Performance in Asymmetric Catalysis
}

\author{
Hendrikus C. L. Abbenhuis, ${ }^{\dagger}$ Urs Burckhardt, ${ }^{\dagger}$ Volker Gramlich, ${ }^{\ddagger}$ \\ Arianna Martelletti, ${ }^{\ddagger}$ J ohn Spencer, ${ }^{\dagger}$ I vo Steiner ${ }^{\dagger}{ }^{\dagger}$ and Antonio Togni ${ }^{\prime}{ }^{\dagger}$ \\ Laboratory of Inorganic Chemistry and Institute of Crystallography and Petrography, \\ Swiss Federal Institute of Technology, ETH-Zentrum, CH-8092 Zurich, Switzerland
}

Received November 21, $1995^{\circledR}$

A route to enantiopure heteroleptic ruthenocenyl derivatives has been found; the diastereoselective addition of $\mathrm{MeLi}$ to (R)- $\mathrm{CyCH}(\mathrm{Me}) \mathrm{N}(\mathrm{Me}) \mathrm{CH}=\mathrm{C}_{5} \mathrm{H}_{4}$ (de $=74 \%$ ), followed by a transmetalation reaction with either $\left[\mathrm{Cp} * \mathrm{Ru}\left(\mu^{3}-\mathrm{Cl}\right)\right]_{4}$ or $\left[\left(\mathrm{p}\right.\right.$-cymene) $\mathrm{RuCl} \mathrm{Cl}_{2} / \mathrm{KPF}_{6}$, afforded the heteroleptic complexes (S,R)-[Cp*Ru( $\left.\left.\eta^{5}-\mathrm{C}_{5} \mathrm{H}_{4} \mathrm{CH}(\mathrm{Me}) \mathrm{N}(\mathrm{Me}) \mathrm{CH}(\mathrm{Me}) \mathrm{Cy}\right)\right], 6$, or $(\mathrm{S}, \mathrm{R})-\left[\left(\mathrm{p} \text {-cymene)Ru( } \eta^{5}-\mathrm{C}_{5} \mathrm{H}_{4} \mathrm{CH}(\mathrm{Me}) \mathrm{N}(\mathrm{Me}) \mathrm{CH}(\mathrm{Me}) \mathrm{Cy}\right)\right]^{+} \mathrm{PF}_{6}{ }^{-}, \mathbf{5}$, in $93 \%$ and $72 \%$ yields, respectively. Whereas 5 displayed a somewhat inert behavior, 6 reacted with $\mathrm{NHMe}_{2}$, in acetic acid, to afford its dimethylamino congener (S)-7 in 93\% yield. The latter was converted in two steps into the bis(phosphine) derivatives (S)-(R)-Cp* $\mathrm{RuC}_{5} \mathrm{H}_{3} \mathrm{CH}(\mathrm{Me}) \mathrm{PCy}_{2} \mathrm{PPh}_{2}-2$, (S)(R)-9, and (S)-(R)-Cp* RuC ${ }_{5} \mathrm{H}_{3} \mathrm{CH}(\mathrm{Me}) \mathrm{PC}_{8} \mathrm{H}_{14} \mathrm{PPh}_{2}-2$, (S)-(R)-10, and into the $\mathrm{P}, \mathrm{N}$ derivative (S)-(R)-Cp*RuC $\left.\mathrm{H}_{3} \mathrm{CH}(\mathrm{Me})\left\{\mathrm{N}_{2} \mathrm{C}_{3} \mathrm{HMe}_{2}-3,5\right) \mathrm{PPh}_{2}\right\}-1,2$, (S)-(R)-11. These products were obtained in $>99 \%$ ee after recrystallization. The ruthenocenyl derivatives were probed for their use as chiral ligands for the palladium-catalyzed enantioselective allylic alkylation and the rhodium catalyzed hydroboration reactions. By employing the ruthenocenyl pyrazole (S)-(R)-11, styrene was converted to (S)-1-phenylethanol with $87 \%$ ee, whereas its isostructural ferrocenyl congener (S)-(R)-16 afforded 94\% ee. The following compounds were characterized by X-ray diffraction: (S,R)-5, (S)-(R)-9, (S)-(R)-10, [((S*)-(R*)-14)Pd $\left.\left(\eta^{3}-\mathrm{C}_{3} \mathrm{H}_{5}\right)\right]^{+}-$ $[\mathrm{OTf}]^{-}\left(\left(\mathrm{S}^{*}\right)-\left(\mathrm{R}^{*}\right)-\mathbf{1 2}\right)$, and $\left[\left(\left(\mathrm{S}^{*}\right)-\left(\mathrm{R}^{*}\right)-\mathbf{9}\right) \mathrm{Pd}\left(\eta^{3}-\mathrm{C}_{3} \mathrm{H}_{5}\right)\right]^{+}[\mathrm{OTf}]^{-}\left(\left(\mathrm{S}^{*}\right)-\left(\mathrm{R}^{*}\right)-\mathbf{1 3}\right)$.

\section{Introduction}

By virtue of their high scope of application as ligands in a range of asymmetric reactions, optically active ferrocenyl phosphines, ${ }^{1}$ exemplified by $\mathbf{1 - 3}$, are becoming of increasing importance (see Chart 1 ). ${ }^{2}$ The facile synthesis of a wide range of such derivatives, by a nucleophilic substitution reaction occurring with retention of configuration at the stereogenic center of the side chain, and the resulting structural diversity on the ferrocenyl unit, allow for a systematic study, and exploitation, of el ectronic and steric effects in enantiosel ective catalysis. ${ }^{2 e}$

\footnotetext{
† Laboratory of Inorganic Chemistry.

₹ Institute of Crystallography and Petrography.

$\otimes$ Abstract published in AdvanceACS Abstracts, February 15, 1996.

(1) For reviews, see: (a) Hayashi, T. In Ferrocenes. Homogeneous Catalysis, Organic Synthesis, Materials Science; Togni, A., Hayashi, T., Eds.; VCH: Weinheim, Germany, 1995; pp 105-142. (b) Sawamura, M.; Ito, Y. Chem. Rev. 1992, 92, 857-871. See also: (c) Hayashi, T.; Mise, T.; Fukushima, M.; Kagotani, M.; Nagashima, N.; Hamada, Y.; Matsumoto, A.; Kawakami, S.; Konishi, M.; Yamamoto, K.; Kumada, M. Bull. Chem. Soc. J pn. 1980, 53, 1138-1151.

(2) For recent reports from our laboratories, see: (a) Togni, A.; Breutel, C.; Schnyder, A.; Spindler, F.; Landolt, H.; Tijani, A. J . Am Chem. Soc. 1994, 116, 4062-4066. (b) Breutel, C.; Pregosin, P. S.; Salzmann, R.; Togni, A. J . Am. Chem. Soc. 1994, 116, 4067-4068. (c) Togni, A.; Breutel, C.; Soares, M. C.; Zanetti, N.; Gerfin, T.; Gramlich, V.; Spindler, F.; Rihs, G. Inorg. Chim. Acta 1994, 222, 213-224. (d) Abbenhuis, H. C. L.; Burckhardt, U.; Gramlich, V.; Köllner, C.; Pregosin, P. S.; Salzmann, R.; Togni, A. Organometallics 1995, 14, 759-766. (e) Schnyder, A.; Hintermann, L.; Togni, A. Angew. Chem. 1995, 107, 996-998 (Angew. Chem. Int. Ed. Engl. 1995, 34, 931-933). (f) Burckhardt, U.; Hintermann, L.; Schnyder, A.; Togni, A. Organometallics 1995, 14, 5415-5425. (g) Spencer, J .; Gramlich, V.; Häusel, R.: Togni A. Tetrahedron: Asymmetry 1996, 7, 41-44. (h) Zanetti, N C.; Spindler, F.; Spencer, J .; Togni, A.; Rihs, G. Organometallics 1996 15, 860. (i) Togni, A.; Burckhardt, U.; Pregosin, P. S.; Salzmann, R. J
} Am. Chem. Soc. 1996, 118, 1031-1037.

\section{Chart 1}

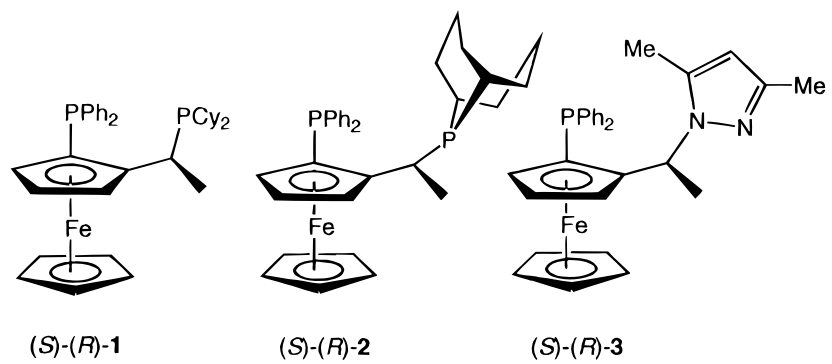

Recently, we reported a new stereosel ective route to congeners of $\mathbf{1}-\mathbf{3}$, with the added advantage of all owing variation of the ("Iower") nonfunctionalized Cp. ${ }^{3}$ The key feature of the underlying synthetic strategy was to construct ferrocenes starting from enantiomerically enriched Cp synthons and a suitable iron(II) precursor. Hence, the synthesis of precursors to anal ogues of 1-3 was possible via a highly stereoselective addition of MeL $\mathrm{i}$ to one diastereotopic face of an enantiomerically pure fulvene derivative, followed by transmetalation with an iron(II) salt. The diaster eosel ectivity observed during the formation of one particular metalated cyclopentadienyl derivative (S,R)-4 was as high as $87 \%$. As a natural extension to this study, it was tempting to test whether this method was amenable for the synthesis of the corresponding heteroleptic ruthenocene complexes, namely by reaction of $\mathbf{4}$ with appropriate ruthe nium(II) derivatives. This choice was potentially

(3) Abbenhuis, H. C. L.; Burckhardt, U.; Gramlich, V.; Togni, A.; Albinati, A.; Müller, B. Organometallics 1994, 13, 4481-4493. 
Scheme 1

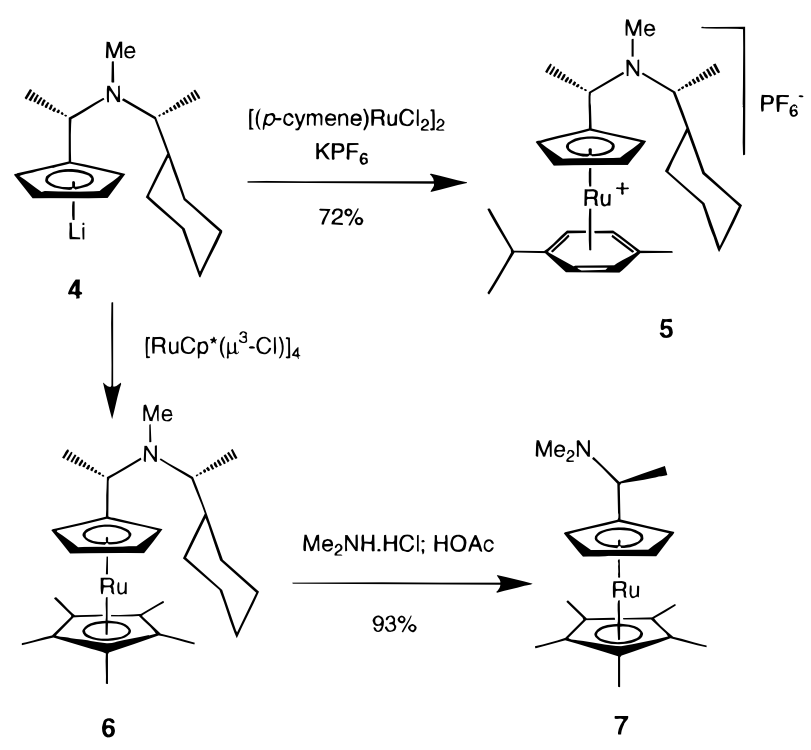

informative, as it would enable a direct comparison of structural and conformational aspects of similar Fe(II) and $\mathrm{Ru}(\mathrm{II})$ systems with a particular emphasis on their respective performances in catalysis. ${ }^{4}$

This account provides full synthetic details for the preparation of new enantiomerically enriched ruthenocenyl amines, as well as their derivatization to give new ligands for transition-metal-catalyzed asymmetric reactions. A comparison of the performance of such ligands with that of their isostructural ferrocenyl analogues is also presented.

\section{Results and Discussion}

Stereoselective Syntheses of Ruthenocenyl P,P and $\mathbf{P}, \mathbf{N}$ Ligands. The "half-sandwich" complexes $\left[\mathrm{Cp} * \mathrm{Ru}\left(u^{3}-\mathrm{Cl}\right)\right]_{4}{ }^{5}$ and $\left[(\mathrm{p} \text {-cymene }) \mathrm{RuCl}_{2}\right]_{2}{ }^{6}$ are convenient starting materials for the synthesis of the requisite heteroleptic Ru sandwich compounds. Transmetalations with the cyclopentadienyl synthon 4 proceed smoothly and afford respectively the cationic ruthenium amine derivative $\mathbf{5}$ and the neutral ruthenocenyl amine 6 (see Scheme 1). The latter is obtained in 93\% yield as a dark oil after conventional workup involving its purification by flash chromatography over silica. The transmetalation of [(p-cymene) $\left.\mathrm{RuCl}_{2}\right]_{2}$ with $\mathbf{4}$, followed by an anion-exchange reaction with $\mathrm{KPF}_{6}$, furnishes the cationic mixed sandwich derivative 5 in $72 \%$ yield as an air stable beige/brown solid. Since the cyclopentadienyl synthon (S,R)-4 contains, due to the incomplete stereosel ectivity in its formation (de $=74 \%$ ), ca. $13 \%$ of the minor diastereoisomer $(\mathrm{R}, \mathrm{R}) \mathbf{- 4}$, the new heteroleptic complexes $\mathbf{5}$ and $\mathbf{6}$ should exist as approximate 7:1 mixtures of diastereoisomers. The ${ }^{1 \mathrm{H}}$ and ${ }^{13} \mathrm{C}$ NMR resonances of the minor isomers, however, are not sufficiently dinstinguishable from those of the major diastereoisomers to allow an assessment of the diastereoisomeric purity of $\mathbf{5}$ or $\mathbf{6}$ by NMR. Gratifyingly,

(4) F or a recent discussion of the differences between ruthenocenyl and ferrocenyl ligands. see: Hayashi, T.; Ohno, A.; Lu, S.; Matsumoto, Y.; Fukuyo, E.; Yanagi, K. J. Am. Chem. Soc. 1994, 116, 4221-4226 and references cited therein.

(5) Fagan, P. J .; Ward, M. D.; Calabrese, J . C. J . Am. Chem. Soc. 1989, 111, 1698-1719.

(6) Bennet, M. A.; Smith, A.J . Chem. Soc., Dalton Trans. 1974, 233.
Scheme 2

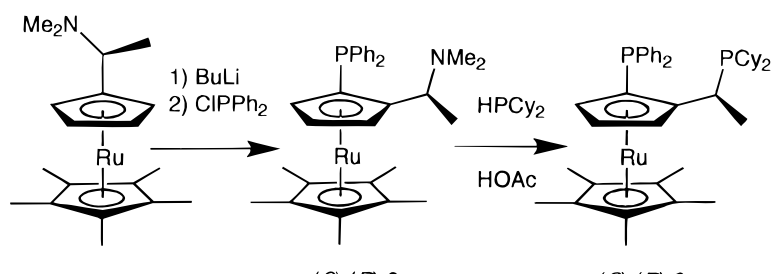

$S-7$

$(S)-(R)-8$

$(S)-(R)-9$

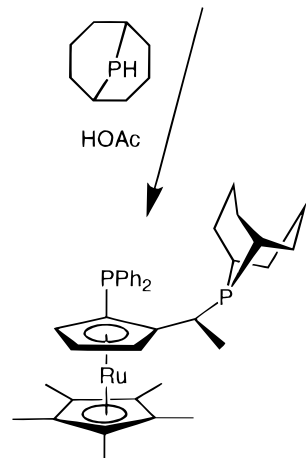

$(S)-(R)-10$

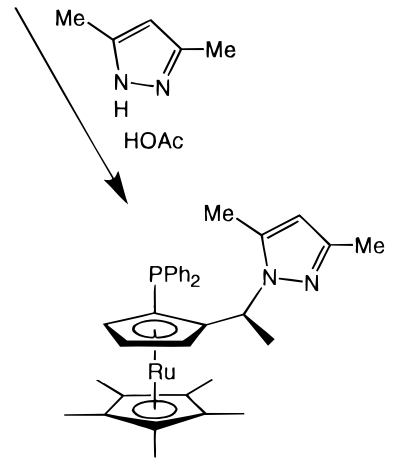

$(S)-(R)-11$ diastereoisomerically pure (S,R)-5 can be easily obtained by crystallization from $\mathrm{CH}_{2} \mathrm{Cl}_{2} / \mathrm{Et}_{2} \mathrm{O}$ mixtures. More over, the absolute configuration of $\mathbf{5}$ was elucidated by an X-ray structural analysis (vide infra). In the case of the ruthenocenyl amine $\mathbf{6}$, which is invariably obtained as an oil, separation of the two diastereoisomers cannot be achieved by a simple crystallization procedure nor by column chromatography. This, however, does not hamper the obtention of virtually enantiomerically pure ruthenocenyl derivatives from 6 (vide infra).

Attempts to ortho-lithiate the ruthenocenyl derivatives $\mathbf{5}$ and $\mathbf{6}$ using n-BuLi were unsuccessful. As we recently reported for the related iron chemistry, this rather inert behavior toward ortho-metalation is ascribed to the presence of sterically demanding substituents at the nitrogen center, which may severely disfavor chelation in the lithiated ruthenocenyl intermediates. With the ruthenocenyl amine 6, this complication can be easily alleviated since virtually quantitative conversion into its dimethylamino analogue 7 (see Scheme 1 ) is readily achieved. In contrast to the purification of $\mathbf{6}$, which involves flash chromatography on silica, attempts to purify $\mathbf{7}$ by a similar procedure were unsuccessful and invariably led to decomposition of the compound to the vinyl complex, $\mathrm{Cp} * \mathrm{RuC}_{5} \mathrm{H}_{4}$ $\mathrm{CH}=\mathrm{CH}_{2}$. Subsequent lithiation of the ruthenocenyl amine 7 with n-BuLi occurs with high stereoselectivity, and the lithiated ruthenocene reacts readily with chlorodiphenylphosphine to give the enantiomerically enriched (diphenyl phosphino)ruthenocenyl amine (S)-(R)-8 (see Scheme 2) in nearly $70 \%$ yield. The diastereoselectivity of this reaction must be greater than $98 \%$, as the (S)-(S)-diastereoisomer could never be identified. The analogous conversion of the cationic ruthenium amine 5 into its dimethylamine derivative could not be achieved. 5 is inert toward $\mathrm{Me}_{2} \mathrm{NH} / \mathrm{HOAc}$ at room temperature for $48 \mathrm{~h}$ or $\mathrm{Me}_{2} \mathrm{NH} \cdot \mathrm{HCl} / \mathrm{KOAC}$ in $\mathrm{HOAc}$ at reflux temperature over similar periods of time. Such a lack of reactivity in this aminolysis reaction is probably due to the inability of the metal center to provide anchimeric assistance prior to solvolysis, as this would necessitate the generation of an unfavorable dicationic 
Table 1. Experimental Data for the X-ray Diffraction Study of $\left(S_{,} \mathbf{R}\right)-5,\left(S^{*}\right)-\left(R^{*}\right)-12$, and $\left(S^{*}\right)-\left(R^{*}\right)-13$

\begin{tabular}{|c|c|c|c|}
\hline & \multicolumn{3}{|c|}{ compound } \\
\hline & \multicolumn{2}{|r|}{$\left(\mathrm{S}^{*}\right)-(\mathrm{R} *)-12$} & $\left(\mathrm{~S}^{*}\right)-(\mathrm{R} *)-13$ \\
\hline $\begin{array}{l}\text { formula } \\
\text { mol wt }\end{array}$ & $\begin{array}{l}\mathrm{C}_{26} \mathrm{H}_{40} \mathrm{~F}_{6} \mathrm{NPRu} \\
612.6\end{array}$ & $\mathrm{C}_{45} \mathrm{H}_{59} \mathrm{~F}_{3} \mathrm{FeO}_{3} \mathrm{P}_{2} \mathrm{PdS} \cdot \mathrm{CH}_{2} \mathrm{Cl}_{2}$ & $\mathrm{C}_{45} \mathrm{H}_{59} \mathrm{~F}_{3} \mathrm{O}_{3} \mathrm{P}_{2} \mathrm{PdRuS}$ \\
\hline cryst $\operatorname{dim}(\mathrm{mm})$ & $0.63 \times 0.4 \times 0.44$ & $0.1 \times 0.2 \times 0.4$ & $0.5 \times 0.25 \times 0.1$ \\
\hline data coll T $\left({ }^{\circ} \mathrm{C}\right)$ & 20 & 20 & 20 \\
\hline cryst syst & orthorhombic & monodinic & monoclinic \\
\hline space goup & $\mathrm{P} 2_{1} 2_{1} 2_{1}$ & $\mathrm{P} 2_{1} / \mathrm{C}$ & $\mathrm{P} 2_{1} / \mathrm{C}$ \\
\hline$a(\AA)$ & $10.575(6)$ & $21.589(8)$ & $23.78(7)$ \\
\hline $\mathrm{b}(\AA)$ & $11.508(7)$ & $13.825(5)$ & $9.693(11)$ \\
\hline$c(\AA)$ & $23.221(14)$ & $18.071(7)$ & $20.83(3)$ \\
\hline$\alpha$ (deg) & & $105.05(3)$ & $110.7(2)$ \\
\hline$V\left(\AA^{3}\right)$ & $2826(3)$ & $5209(3)$ & $4490(15)$ \\
\hline Z & 4 & 4 & 4 \\
\hline$\rho($ calcd $)\left(\mathrm{g} \cdot \mathrm{cm}^{-3}\right)$ & 1.440 & 1.424 & 1.489 \\
\hline$\mu\left(\mathrm{cm}^{-1}\right)$ & 6.66 & 9.78 & 9.05 \\
\hline$F(000)$ & 1264 & 2296 & 2064 \\
\hline diffractometer & \multirow{2}{*}{\multicolumn{3}{|c|}{ Mo K $\alpha$ (graphite monochrom), $\lambda=0.71073 \AA$}} \\
\hline radiation & & & \\
\hline measd reflcns & $\begin{array}{c}0 \leq \mathrm{h} \leq 10,0 \leq \mathrm{k} \leq 11 \\
0 \leq / \leq 22\end{array}$ & $\begin{array}{c}0 \leq \mathrm{h} \leq 20,-13 \leq \mathrm{k} \leq 0 \\
-17 \leq / \leq 16\end{array}$ & $\begin{array}{c}0 \leq h \leq 14,-7 \leq k \leq 7, \\
-15 \leq / \leq 14\end{array}$ \\
\hline $2 \theta$ range $(\mathrm{deg})$ & $3.0-4.0 .0$ & $3.0-40.0$ & $3.0-40.0$ \\
\hline scan type & $\omega$ & $\omega$ & $\omega$ \\
\hline scan width (deg) & 1.00 & 1.00 & 1.05 \\
\hline bkgd time (s) & $0.30 \times$ scan time & $0.25 \times$ scan time & $0.25 \times$ scan time \\
\hline max scan speed $\left(\mathrm{deg} \cdot \mathrm{min}^{-1}\right)$ & $1.0-4.0$ in $\omega$ & $1.0-4.0$ in $\omega$ & $1.0-4.0$ in $\omega$ \\
\hline no. of indep data coll & 1535 & 4851 & 1739 \\
\hline no. of obsd reflans $\left(n_{0}\right)$ & $\begin{array}{l}1387 \\
\left|F_{o}^{2}\right|>4.0 \rho\left(|F|^{2}\right)\end{array}$ & $\begin{array}{l}3551 \\
\left|F_{0}^{2}\right|>4.0 \rho\left(|F|^{2}\right.\end{array}$ & $\begin{array}{l}1475 \\
\left|F_{o}^{2}\right|>4.0 \rho\left(|F|^{2}\right)\end{array}$ \\
\hline $\begin{array}{l}\text { abs corr } \\
\text { transm coeff }\end{array}$ & N/A & N/A & $\begin{array}{l}\text { face-indexed numerical } \\
0.9079-0.9582\end{array}$ \\
\hline no. of params refined $\left(n_{v}\right)$ & 304 & 545 & 450 \\
\hline $\begin{array}{l}\text { quantity minimized } \\
\text { weighting scheme }\end{array}$ & $\begin{array}{l}\sum \mathrm{w}\left(\mathrm{F}_{\mathrm{o}}-\mathrm{F}_{\mathrm{c}}\right)^{2} \\
\mathrm{~W}^{-1}=\sigma^{2}(\mathrm{~F})+0.0134 \mathrm{~F}^{2}\end{array}$ & $\begin{array}{l}\sum \mathrm{w}\left(\mathrm{F}_{\mathrm{o}}-\mathrm{F}_{\mathrm{c}}\right)^{2} \\
\mathrm{w}^{-1}=\sigma^{2}(\mathrm{~F})+0.0023 \mathrm{~F}^{2}\end{array}$ & $\begin{array}{l}\sum \mathrm{w}\left(\mathrm{F}_{\mathrm{o}}-\mathrm{F}_{\mathrm{c}}\right)^{2} \\
\mathrm{w}^{-1}=\sigma^{2}(\mathrm{~F})+0.0010 \mathrm{~F}^{2}\end{array}$ \\
\hline $\mathrm{R}^{\mathrm{a}}$ & 0.0595 & 0.0657 & 0.0419 \\
\hline $\mathrm{R}_{\mathrm{w}}^{\mathrm{b}}$ & 0.0797 & 0.0926 & 0.0544 \\
\hline $\mathrm{GOF}^{\mathrm{c}}$ & 0.75 & 1.64 & 1.70 \\
\hline
\end{tabular}

species. Consequently, we aborted further efforts to synthesize cationic ruthenocenyl phosphines from $\mathbf{5}$ and restricted the work presented herein on the use of (diphenylphosphino)ruthenocenyl amine (S)-(R)-8.

As with its iron anal ogue, the amine (S)-(R)-8 can be easily obtained in highly enantiomerically enriched form (>99\% ee) by selective crystallization of the racemate ( $\left.\mathrm{S}^{*}\right)-\left(\mathrm{R}^{*}\right)$-8 from ethanol solutions of the enantiomerically enriched compound. It is important to note that the multistep synthesis of $\mathbf{8}$ from the chiral Cp synthon 4 is accompanied with no net loss of optical activity. This can be derived from analysis of the relative amounts of $\left(S^{*}\right)-\left(R^{*}\right)-8$ and $(S)-(R)-8$ which nicely mirror the diastereoselectivity observed during the generation of $\mathbf{4}$. Subsequent derivatization of (S)-(R)-8 by applying a series of standard transformations, all of which have precedence in the related ferrocenyl series, ${ }^{3}$ enabled access to ligands (S)-(R)-9-11 (see Scheme 2). The first member of this series, (S)-(R)-9, was obtained as yellow crystals in $62 \%$ yield, after chromatographic purification, by the substitution of the dimethylamino group of (S)-(R)-8 with dicyclohexylphosphine in acetic acid. The phobyl (9-phospha[3.3.1]bicyclonon-9-yl) incorporating compound (S)-(R)-10 was equally prepared from (S)(R)-8 as a yellow solid in $40 \%$ yield in an analogous manner using a technical mixture of phobane as phosphine source. ${ }^{2 d}$ The yellow solid (S)-(R)-11 was synthesized from (S)-(R)-8 using 3,5-dimethylpyrazole as nucleophile. Given that the diamagnetic shift reagent R-(-)-1-(9-anthryl)-2,2,2-trifluoroethanol was effective for the separation of the resonances of the racemic pyrazole ligand ( $\left.\mathrm{S}^{*}\right)-\left(\mathrm{R}^{*}\right)-\mathbf{- 1 1}$ by ${ }^{1} \mathrm{H}$ NMR, the ee of (S)(R)-11 was confirmed to be greater than 99\%. The optical purity of the ligands (S)-(R)-9 and $\mathbf{1 0}$ was checked by HPLC (see Experimental Section).

Solid State Structures of the Ruthenocenyl Derivatives (S,R)-5, (S)-(R)-9, and (S)-(R)-10. In order to establish the stereochemical integrity and to study conformational aspects, we carried out X-ray crystallographic studies on the new heteroleptic ruthenium sandwich derivatives (S,R)-5, (S)-(R)-9, and (S)(R)-10. For comparative purposes it was especially indispensable to obtain data for the latter two ligands so as to assess the effect of a change in metal, from $\mathrm{Fe}$ to $\mathrm{Ru}$, on, for example, the relative positions of the aryl groups of the diphenyl phosphine fragment of the upper $\mathrm{Cp}$ ring and the flexibility of the metallocene unit as a whole. An ORTEP view of the first of this series, $(S, R)$ 5, is shown in Figure 1, and Table 1 collects crystal data and refinement parameters. The ruthenium atom is embedded in a mixed sandwich comprising the $\eta^{6}$-bound $\mathrm{p}$-cymene and $\eta^{5}$-bound $\mathrm{Cp}$ fragment derived from $(\mathrm{S}, \mathrm{R})$ 4. Bond lengths and angles turn out to be routine and compare with those of, e.g., the similar cationic mixed sandwich derivative $\left[\mathrm{Cp} * \mathrm{Ru}\left(\eta^{6}-\mathrm{C}_{6}\left(\mathrm{CH}_{3}\right)_{6}\right)\right]^{+} .5$ The present structural study proves the absolute configuration $\mathrm{S}$ at the C(6) stereogenic center, thus directly establishing the stereochemistry of the preferred diastereoisomer of cyclopentadienyl 4.

Crystal data and ORTEP views of compounds $\mathbf{9}$ and $\mathbf{1 0}$ are provided as Supporting I nformation. The structure of derivative $\mathbf{9}$ can be compared to that of the 


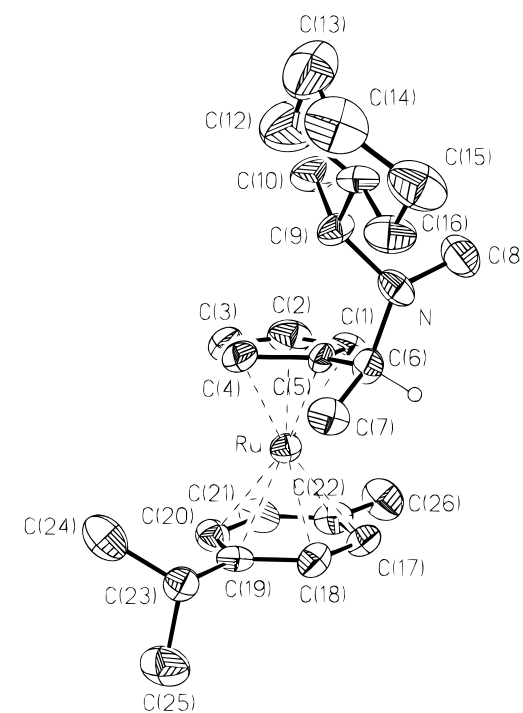

Figure 1. ORTEP view of the cation (S,R)-5 (30\% probability ellipsoids). The Ru atom is located at $1.831 \AA$ from the $\mathrm{Cp}$ ring and $1.703 \AA$ from the $\mathrm{p}$-cymene ring. The planes of the two rings subtend an angle of $3.8^{\circ}$.

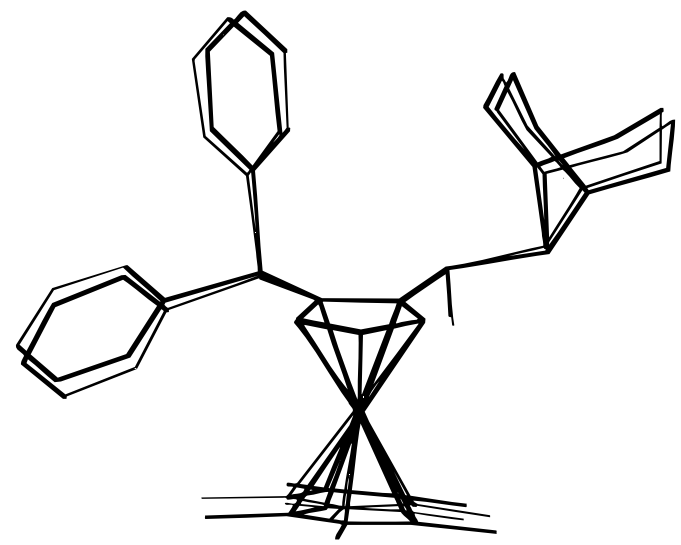

Figure 2. Schematic superposition of the structures of (S)(R)-10 and (S)-(R)-15, ${ }^{3}$ showing the virtually identical conformation in the solid state.

corresponding Fe parent compound, J osiphos, 1, reported recently from these laboratories. ${ }^{2 c}$ The only significant difference, besides the Ru-Cp (vs Fe-Cp) distances, pertains to the relative orientation of the cyclohexyl rings, indicating that the $\mathrm{PCy}_{2}$ group constitutes the conformationally most flexible part of the molecule. The structural features of compound $\mathbf{1 0}$ are, not surprisingly, virtually identical to those of the corresponding Fe derivative $\mathbf{1 5}$ (see Chart 2), discussed in detail previously. ${ }^{3}$ The only obvious difference is the increased $\mathrm{Cp}-\mathrm{Cp}$ * distance in $\mathbf{1 0}$ (Ru-Cp $1.824 \AA$ and $\mathrm{Ru}-\mathrm{Cp} * 1.808 \AA$ ), as compared to $\mathbf{1 5}$. The similarity of derivative $\mathbf{1 0}$ with its Fe congener is illustrated in the schematic superposition of the two structures given as Figure 2.

On the basis of the conformational characteristics observed for the free ligands $\mathbf{9}$ and $\mathbf{1 0}$, as compared with similar Fe derivatives, one would anticipate no important differences between the Ru- and Fe-containing ligands, respectively, in their coordination behavior and hence in the catalytic performances of their complexes. As we will discuss below, this conclusion turns out to be incorrect, because of further unexpected features of the complexes containing the heavier element Ru.

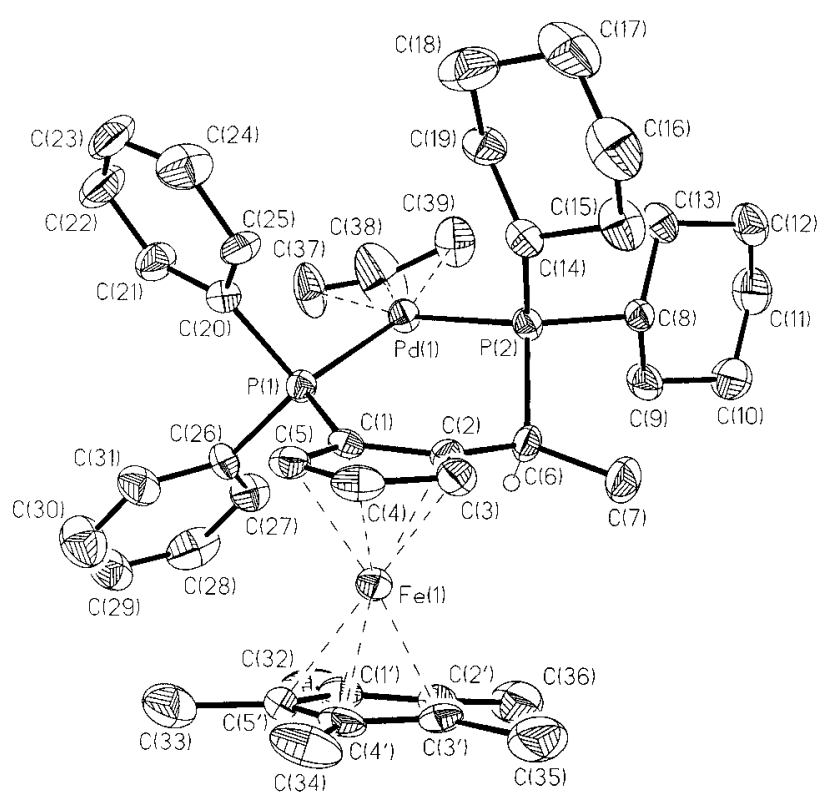

Figure 3. ORTEP view of the cation $\left(\mathrm{S}^{*}\right)-\left(\mathrm{R}^{*}\right)-\mathbf{1 2}(30 \%$ probability ellipsoids).

Structural Comparison of Palladium $\eta^{3}$-Allyl Complexes Incorporating Ruthenocenyl and Ferrocenyl Phosphines. Having established a marked similarity of the structural/conformational attributes of the Ru-containing ligands, when compared to the corresponding $\mathrm{Fe}$ derivatives, it was now necessary to compare the two systems as ligands. We opted for the facile synthesis and structural characterization of their cationic palladium $\eta^{3}$-allyl complexes, following procedures al ready empl oyed in our laboratory. ${ }^{2 d}$ The racemic ruthenocene $\left(S^{*}\right)-\left(R^{*}\right)-\mathbf{9}$ and its isostructural bis(phosphine) iron analogue $\left(\mathrm{S}^{*}\right)-\left(\mathrm{R}^{*}\right)$-14 were chosen as ligands (eq 1).

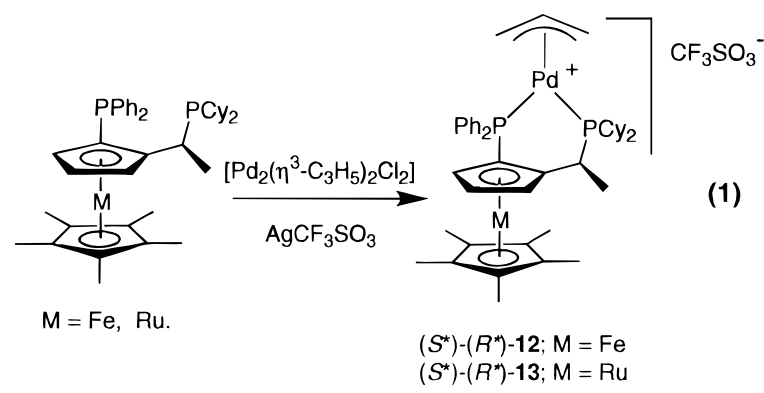

The single-crystal $\mathrm{X}$-ray structures of the resulting palladium $\eta^{3}$-allyl complexes ( $\left.\mathrm{S}^{*}\right)$-( $\left.\mathrm{R}^{*}\right)$-12 and $\left(\mathrm{S}^{*}\right)$-( $\left.\mathrm{R}^{*}\right)$ 13 were consequently determined. Their ORTEP views are shown in Figures 3 and 4, respectively. Crystal and refinement parameters are given in Table 1, and Table 2 collects pertinent bond lengths and angles, and torsion angles for both compounds.

Again, for the sake of simplicity, it is appropriate to compare the structure of complex $\mathbf{1 2}$ with that of the known compound containing the nonmethylated ligand J osi phos (1). ${ }^{2 c}$ The superposition of the two structures, shown in Figure 5 , indicates a strong similarity of the conformational features. At first sight, the only relevant effect due to the addition of five $1^{\prime}-5^{\prime}$ methyl groups in $\mathbf{1 2}$ is shown by the relative position and orientation of the $\mathrm{PPh}_{2}$ group. It turns out that the latter is "pushed up" even more than in the parent compound. This is 


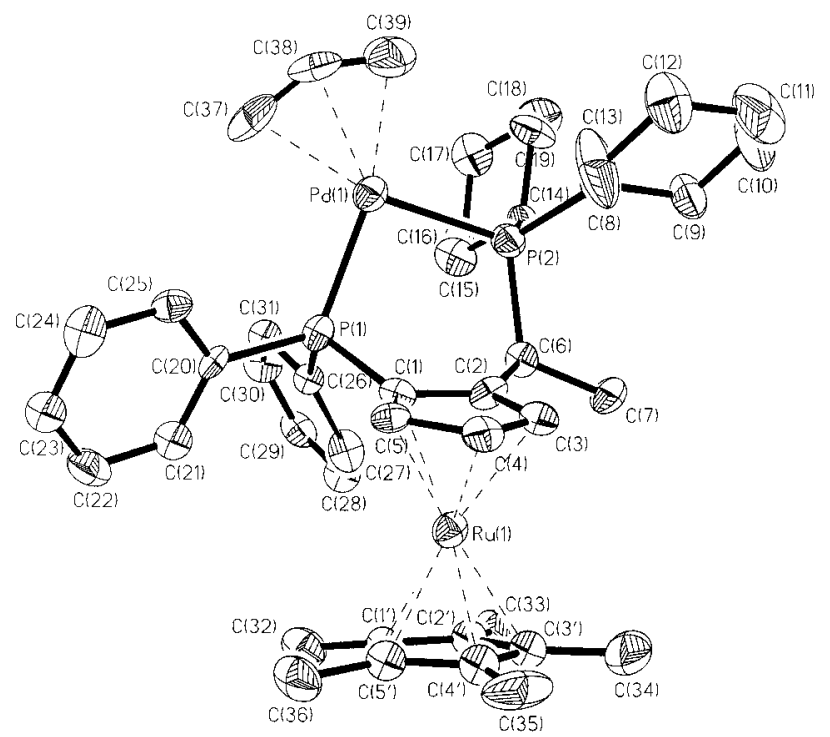

Figure 4. ORTEP view of the cation $\left(S^{*}\right)-\left(R^{*}\right)-\mathbf{1 3}(30 \%$ probability ellipsoids).

Table 2. Selected Bond Distances $(\AA),{ }^{a}$ Angles (deg), and Torsion Angles (deg) for $\left(S^{*}\right)-\left(R^{*}\right)-12$ and $\left(\mathbf{S}^{*}\right)-\left(\mathbf{R}^{*}\right)-13$

\begin{tabular}{lcl}
\hline & $\left(\mathrm{S}^{*}\right)-\left(\mathrm{R}^{*}\right)-\mathbf{1 2}$ & $\left(\mathrm{R}^{*}\right)-\left(\mathrm{S}^{*}\right)-\mathbf{1 3}$ \\
\hline & Bond Distances & \\
$\mathrm{Pd}-\mathrm{P}(1)$ & $2.295(3)$ & $2.285(8)$ \\
$\mathrm{Pd}-\mathrm{P}(2)$ & $2.312(3)$ & $2.353(8)$ \\
$\mathrm{Pd}-\mathrm{C}(37)$ & $2.207(15)$ & $2.163(27)$ \\
$\mathrm{Pd}-\mathrm{C}(38)$ & $2.129(20)$ & $2.108(35)$ \\
$\mathrm{Pd}-\mathrm{C}(39)$ & $2.180(13)$ & $2.118(25)$ \\
$\mathrm{M}-\mathrm{C} \mathrm{p}^{*}$ & 1.678 & 1.805 \\
$\mathrm{M}-\mathrm{Cp}$ & 1.661 & 1.819 \\
& Bond Angles & \\
$\mathrm{P}(1)-\mathrm{Pd}-\mathrm{P}(2)$ & $95.3(1)$ & $94.0(2)$ \\
$\mathrm{P}(1)-\mathrm{Pd}-\mathrm{C}(37)$ & $95.2(4)$ & $100.3(6)$ \\
$\mathrm{P}(2)-\mathrm{Pd}-\mathrm{C}(39)$ & $102.8(4)$ & $99.3(7)$ \\
$\mathrm{Pd}-\mathrm{P}(1)-\mathrm{C}(1)$ & $116.6(4)$ & $106.2(6)$ \\
$\mathrm{Pd}-\mathrm{P}(2)-\mathrm{C}(6)$ & $106.3(3)$ & $112.4(6)$ \\
$\mathrm{C}(37)-\mathrm{C}(38)-\mathrm{C}(39)$ & $141.4(23)$ & $148.7(36)$ \\
$\mathrm{Cp}-\mathrm{C} \mathrm{p}^{*}$ & 9.0 & 12.6 \\
& Torsion Angles & \\
$\mathrm{Pd}-\mathrm{P}(1)-\mathrm{C}(1)-\mathrm{C}(2)$ & 8 & 53 \\
$\mathrm{Pd}-\mathrm{P}(2)-\mathrm{C}(6)-\mathrm{C}(2)$ & 73 & 48 \\
$\mathrm{P}(1)-\mathrm{C}(1)-\mathrm{C}(5)-\mathrm{C}(4)$ & 162 & 158 \\
$\mathrm{C}(4)-\mathrm{C}(3)-\mathrm{C}(2)-\mathrm{C}(6)$ & 180 & 167 \\
$\mathrm{P}(2)-\mathrm{C}(6)-\mathrm{C}(2)-\mathrm{C}(1)$ & 62 & 68
\end{tabular}

${ }^{a}$ Numbers in parentheses are esd's in the least significant digits.

clearly because of severe nonbonding interactions between the protruding $\mathrm{Cp}^{*}$ ligand and the $\mathrm{C}(26)-\mathrm{C}(31)$ phenyl group, as illustrated by (1) the short distance between the plane defined by the latter and the methyl group C(32) of $3.33 \AA$ (shortest atom to atom separation is $C(28)-C(32)$ of $3.53 \AA)$, (2) the $C p-C p^{*}$ angle of $9^{\circ}$, and (3) the out-of-plane position of the phosphorus atom $P(1)$. Its distance from the plane of the "upper" Cp ring is now $0.49 \AA$ (vs $0.29 \AA$ for the parent compound). Whereas in the J osiphos-containing complex one could describe the two phenyl groups in terms of axial and equatorial positions for the "lower" and the "upper" aryl, respectively, this distinction no longer applies to 12. Both substituents on $\mathrm{P}(1)$ assume pseudo-equatorial positions. The conformation of the rest of the molecule is very similar in both compounds. Finally, from a qualitative point of view, the overall conformation of the Fe-containing ligand $\mathbf{1 4}$ in the $\mathrm{Pd}$-allyl complex 12

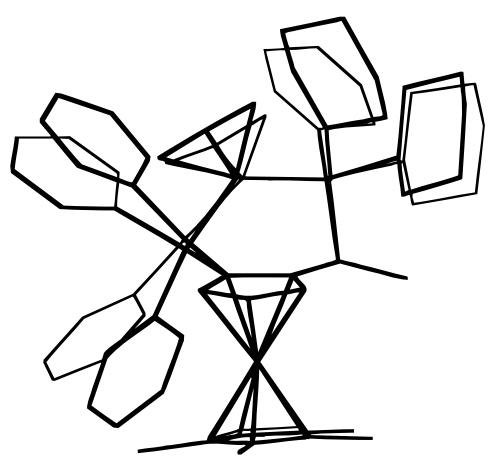

Figure 5. Schematic superposition of the structures of the cation ( $\left.S^{*}\right)-\left(R^{\prime \prime}\right)-\mathbf{1 2}$ and the corresponding complex containing the ligand J osiphos (1), ${ }^{2 c}$ showing the very similar conformation in the solid state.

matches very well the one of the free parent ligand $\mathrm{J}$ osiphos. On the basis of these considerations only, one is tempted to assume that the replacement of the unsubstituted $\mathrm{Cp}$ by $\mathrm{Cp}$ *, and, by extension, even more so the introduction of Ru instead of $\mathrm{Fe}$, would not have very significant consequences on the conformational properties of the respective complexes. Therefore, if ground-state conformational considerations on complexes are important in the discussion of the catalytic performance of the different ligands, it could be anticipated that the three ligands J osiphos, 9, and 14 should behave in a comparable manner.

The structure of the Ru derivative 13, however, shows some unusual and unexpected features. First of all, the orientation of the $\mathrm{Pd}$-allyl fragment turns out to be completely different from that found in the analogous complex 12. The Pd atom seems to adopt the most remote position from the ruthenocene core. This is illustrated by the large angle subtended by the planes of the Cp ring and the one defined by the atoms $\mathrm{Pd}$, $P(1)$, and $P(2)$ of $76^{\circ}$ (vs $22.5^{\circ}$ for the corresponding angle in 12). The most astonishing related feature is the orientation of the two Ph groups on $\mathrm{P}(1)$. Both are in a pseudo-equatorial position, pointing "down", i.e. toward the $C p^{*} R u$ fragment. The steric repulsion between the $\mathrm{Ph}$ groups and the $\mathrm{Cp}$ * ligand (shortest nonbonding distance is $3.47 \AA$ for $C(27)-C(32))$ is relieved by the severe distortion around $C(1)$, with $P(1)$ located $0.56 \AA$ above the $\mathrm{Cp}$ plane. This distortion is in part also transmitted to $C(2)$, with $C(6)$ positioned at $0.25 \AA$ (vs $0.01 \AA$ in 12) from the same plane. These features seem to indicate an enhanced deformability of the ruthenocene core, as compared to ferrocene, in this class of compounds. A tentative conclusion from these observations is that complexes containing ruthenocenyl ligands will be conformationally more flexible than their ferrocenyl counterparts.

Asymmetric Catalysis Involving the Ruthenocenyl Derivatives (S)-(R)-9-11 as Ligands. Carrying on from our very successful exploitation of ligands 1-3 in a wide range of asymmetric processes, often giving rise to ee's well in excess of $90 \%$, a few catalytic applications of the new ruthenocenes (S)-(R)-9-11 were attempted. Two routine reactions were performed, viz. the palladium-catalyzed alkylation of 1,3-diphenyl-3acetoxypropene with dimethyl mal onate (see Table 3), ${ }^{7}$ and the rhodium-catalyzed hydroboration of styrene (see Table 4). ${ }^{8}$ As a comparison, the recently introduced 
Table 3. Palladium-Catalyzed Alkylation of 1,3-Diphenyl-3-Acetoxypropene with Dimethyl Malonate

\begin{tabular}{ccccc}
\hline entry & ligand & time $(\mathrm{h})$ & conversion (\%) & \% ee (abs conf) \\
\hline 1 & (S)-(R)-9 & 0.5 & 53 & $77(\mathrm{R})$ \\
2 & (S)-(R)-9 & 36 & 100 & $73(\mathrm{R})$ \\
3 & (S)-(R)-14 & 0.75 & 15 & $78(\mathrm{R})$ \\
4 & (S)-(R)-14 & 50 & 28 & $77(\mathrm{R})$ \\
5 & (S)-(R)-10 & 44 & 22 & $21(\mathrm{~S})$ \\
6 & (S)-(R)-10 & 92 & 26 & $18(\mathrm{~S})$ \\
7 & (S)-(R)-11 & 44 & 10 & $28(\mathrm{~S})$ \\
8 & (S)-(R)-11 & 96 & 100 & $27(\mathrm{~S})$
\end{tabular}

a Catalytic experiments were carried out as described in ref $2 \mathrm{a}$ using $1.0 \mathrm{~mol} \%$ of catalyst at $20^{\circ} \mathrm{C}$.

Table 4. Rhodium-Catalyzed Hydroboration of Styrene $^{a}$

\begin{tabular}{cccccc}
\hline entry & ligand & $\mathrm{T}\left({ }^{\circ} \mathrm{C}\right)$ & time (h) & $\begin{array}{c}\text { regio- } \\
\text { selectivity }\end{array}$ & $\%$ ee (abs conf) \\
\hline 1 & (S)-(R)-9 & 20 & 7 & 95 & $40(\mathrm{~S})$ \\
2 & (S)-(R)-9 & 0 & 7 & 99 & $37(\mathrm{~S})$ \\
3 & (S)-(R)-14 & 20 & 18 & 95 & $54(\mathrm{~S})$ \\
4 & (S)-(R)-10 & 20 & 7 & 89 & $34(\mathrm{~S})$ \\
5 & (S)-(R)-10 & 0 & 7 & 88 & $26(\mathrm{~S})$ \\
6 & (S)-(R)-15 & 20 & 18 & 77 & $32(\mathrm{~S})$ \\
7 & (S)-(R)-11 & 20 & 18 & 67 & $87(\mathrm{R})$ \\
8 & (S)-(R)-16 & 20 & 18 & 76 & $94(\mathrm{R})$ \\
9 & (S)-(R)-16 & 0 & 18 & 68 & $92(\mathrm{R})$
\end{tabular}

a Catalytic experiments were carried out as described in ref $2 a$ using $1.0 \mathrm{~mol} \%$ of catalyst. Complete conversion of the starting material styrene was achieved in all cases listed here. Regioselectivity refers to \% of 1-phenylethanol.

\section{Chart 2}

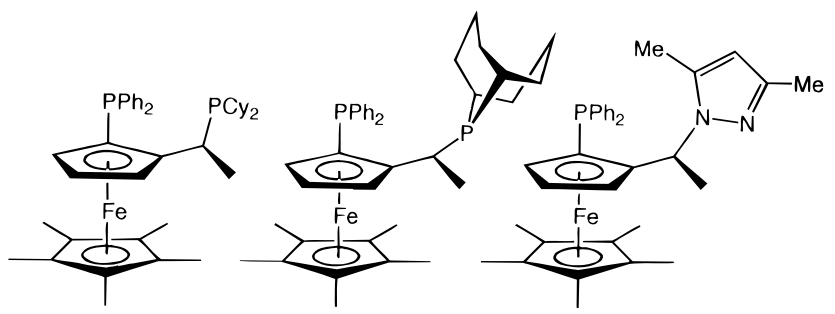

$(S)-(R)-14$

$(S)-(R)-15$

$(S)-(R)-16$

isostructural ferrocenyl derivatives (S)-(R)-14-16 were also tested (see Chart 2).

From Table 3, a few important conclusions can be drawn. It is apparent that the activities of the catalysts are rather low; quantitative conversion of the allylic substrate when employing compounds (S)-(R)-9 and (S)(R)-11 is only achieved after 36 and $96 \mathrm{~h}$, respectively (entries 2 and 8 , Table 3). For the other catalysts

(7) F or reviews, see: (a) Consiglio, G.; Waymouth, R. M. Chem. Rev. 1989, 89, 257-276. (b) Hayashi, T. In Catalytic Asymmetric Synthesis; Ojima, I., Ed.; VCH: New York, 1993; pp 325-365. (c) Godleski, S. A. In Comprehensive Organic Synthesis; Trost, B. M., Fleming, I., Eds.; Pergamon: Oxford, U.K., 1991; Vol. 4, Chapter 3.3, pp 585-661. (d) Frost, C. G.; Howarth, J .; Williams, J . M. J . Tetrahedron: Asymmetry 1992, 3, 1089-1122. For a recent example, see: (e) von Matt, P.; LloydJ ones, G. C.; Minidis, A. B. E.; Pfaltz, A.; Macko, L.; Neuburger, M.; Zehnder, M.; Rüegger, H.; Pregosin, P. S. Helv. Chim. Acta 1995, 78, 265-284 and references cited therein.

(8) For a recent review, see: (a) Burgess, K.; Ohlmeyer, M. J . in Homogeneous Transition Metal Catalyzed Reactions (Adv. Chem. Ser. 230); (Moser, W. R., Slocum, D. W., Eds.; American Chemical Society: Washington, DC, 1992; pp 163-177 and references cited therein. For specific examples, see: (b) Hayashi, T.; Matsumoto, Y.; I to, Y.J . Am. Chem. Soc. 1989, 111, 3426-3428. (c) Matsumoto, Y.; Hayashi, T. Tetrahedron Lett. 1991, 32, 3387-3390. (d) Hayashi, T.; Matsumoto, Y.; I to, Y. Tetrahedron: Asymmetry 1991, 2, 601-612. (e) Burgess, K.; van der Donk, W. A.; Ohlmeyer, M. J . Tetrahedron: Asymmetry 1991, 2, 613-621. (f) Brown, J . M.; Hulmes, D. I.; Layzell, T. P. J . Chem. Soc., Chem. Commun.1993, 1673-1674. employed low conversions were observed even after as much as $92 \mathrm{~h}$. The enantioselectivities observed for these reactions are equally rather low, reaching a maximum of $78 \%$, after $0.75 \mathrm{~h}$ of reaction, for the ferrocenyl ligand (S)-(R)-14, although the activity of this catalyst is hampered by its low stability and rapid deactivation; even after $50 \mathrm{~h}$ only $28 \%$ conversion is attained. It is pertinent to note that the nonmethylated parent ligand $\mathbf{1}$ gave $93 \%$ ee and $99 \%$ yield for the same reaction after only $3 \mathrm{~h}$. F or the ruthenocenyl ligands employed in these tests very disappointing ee's and activities were observed, (S)-(R)-10 and (S)-(R)-11 giving ee's much lower than 30\%, and the opposite enantiomer was obtained in each case. As with the ferrocene (S)(R)-14, these reactions (entries 5-8) suffered from catalyst deactivation over prolonged periods.

The rhodium-catalyzed hydroboration of styrene continues to be an active subject of research in ours and other laboratories. ${ }^{2 e, 8}$ Our results obtained with the new ligands presented in Table 4 show certain useful trends. Once again, the incorporation of a $\mathrm{Cp}^{*}$ fragment into the ferrocenyl ligand (S)-(R)-14 has a detrimental effect on the enanti oselectivity. Thus, whereas (R)-(S)-1 is an extremely useful ligand for this reaction $(91.5 \%$ ee at $-78^{\circ} \mathrm{C}$ ), (S)-(R)-14 is rather disappointing ( $54 \%$ ee, entry 3 , Table 4), as is the corresponding ruthenocene, (S)(R)-9 (40\% ee). In line with our previously reported observations, the best results are obtained with ligands incorporating pyrazole functions, although in these cases the regioselectivity of the reaction is rather low. Thus, the ruthenocenyl derivative (S)-(R)-11 as ligand yields (S)-1-phenylethanol with an ee of $87 \%$ and $67 \%$ regioselectivity, whereas the ferrocenyl derivative (S)(R)-16 yields the same alcohol with an ee of 94\% accompanied with a significantly higher regioselectivity (76\%) (entries 7 and 8). The highest regio and enantioselectivities were attained with the latter ligand at 20 ${ }^{\circ} \mathrm{C}$.

\section{Conclusions}

Hayashi et al. recently reported an improvement in the enantioselectivity of a number of palladium-catalyzed allylic substitution reactions on moving from a ferrocenyl to a ruthenocenyl bis(phosphine) system, whereby one phosphino fragment was situated on the upper and the other on the lower Cp ring. ${ }^{4}$ Here, the greater distance between the cyclopentadienyl rings in the ruthenocene system leads to a larger bite angle. This was postulated to engender a tighter arrangement of the substituents on the phosphorus atoms, thus creating a more rigid "chiral pocket". Our system is significantly different from the latter in that in our case the two chelating fragments, viz. PP or PN functions, are located on the same, upper cyclopentadienyl ring. The unexpected structural features of complex $\mathbf{1 3}$ are interpreted as an expression of the greater conformational flexibility associated with our ruthenocenyl system, translating into a less efficient transmission of the chiral information in the catalytic reactions. In the $\mathrm{Cp}^{*}$ ferrocene system, the larger lower ring seems to be responsible for a general decrease in activity in the Pd-catalyzed allylic chemistry, probably because of a much slower oxidative addition of the substrate, caused by unfavorable steric interactions. On the other hand, the Cp* ligand does not have any detrimental effects in the Rh- 
catalyzed hydroboration of styrene, and indeed ligand $\mathbf{1 6}$ gives virtually identical results as its nonmethylated congener. ${ }^{1 e}$ We interpret this result as indicative of very similar structural/conformational properties of the two catalytically active complexes, not being influenced by the steric nature of the lower $\mathrm{Cp}$ ring.

The present work has shown that structural variations in peripheral regions of metallocene ligands may change their catalytic properties in a drastic manner. We demonstrated that (1) the introduction of a Cp* fragment in our ferrocenyl ligands, instead of a nonsubstituted cyclopentadienyl, and (2) the replacement of Fe by Ru, respectively, has different consequences on their catalytic performances. For diphosphine derivatives forming six-membered chel ate rings, both changes have detrimental effects. In the case of the pyrazolecontaining derivatives forming seven-membered chelates, the influence of both the $\mathrm{Cp}^{*}$ and ruthenium is much less pronounced.

\section{Experimental Section}

General Considerations. All reactions with air- or moisture-sensitive materials were carried out under Ar using standard Schlenk techniques. Freshly distilled, dry, and oxygen-free solvents were used throughout. Technical grade phobane was obtained by courtesy of Prof. A. Salzer, RWTH Aachen, and was used as received. Routine ${ }^{1} \mathrm{H}(250.133 \mathrm{MHz})$, ${ }^{13} \mathrm{C}(62.90 \mathrm{MHz})$, and ${ }^{31} \mathrm{P}(101.26 \mathrm{MHz})$ spectra were recorded with a Bruker AC 250 spectrometer. Chemical shifts are given in ppm and coupling constants $(\mathrm{J})$ are given in hertz. Merck silica gel 60 (70-230 mesh) was used for column chromatography. Optical rotations were measured with a Perkin-EImer 341 polarimeter using $10 \mathrm{~cm}$ cells. Elemental analysis were performed by the "Mikroelementar-analytisches Laboratorium der ETH". Catalytic experiments and analysis of reaction products were carried out as previously described. ${ }^{2 a}$

$(\mathrm{S}, \mathrm{R})-\left[(\mathrm{p}-\mathrm{cymene}) \mathrm{Ru}\left(\mathrm{C}_{5} \mathrm{H}_{4} \mathrm{CH}(\mathrm{Me}) \mathrm{N}(\mathrm{Me}) \mathrm{CH}(\mathrm{Me}) \mathrm{Cy}\right)\right]^{+}-$ $\left[\mathbf{P F}_{\mathbf{6}}\right]^{-}\left(\mathbf{( S , R ) - 5 ) .}\right.$ A cooled THF solution $\left(-40^{\circ} \mathrm{C}\right)$ of $\mathrm{LiC}_{5} \mathrm{H}_{4}{ }^{-}$ $\mathrm{CH}(\mathrm{Me}) \mathrm{N}(\mathrm{Me}) \mathrm{CH}(\mathrm{Me}) \mathrm{Cy}$ (freshly prepared from $0.82 \mathrm{~g}$ (3.8 $\mathrm{mmol}$ ) of (R)- $\mathrm{C}_{5} \mathrm{H}_{4}=\mathrm{CHN}(\mathrm{Me}) \mathrm{CH}(\mathrm{Me}) \mathrm{Cy}$ and $2.4 \mathrm{~mL}$ of $1.6 \mathrm{M}$ MeLi (3.8 mmol) at $0{ }^{\circ} \mathrm{C}$ ) was transferred via cannula to a THF (15 mL) suspension of [(p-cymene)RuCl $]_{2}(1.1 \mathrm{~g}, 1.9 \mathrm{mmol})$ that was also kept at $-40^{\circ} \mathrm{C}$. After being warmed up to room temperature and stirred for $1.5 \mathrm{~h}$, the resulting red solution was filtered and the filtrate evaporated in vacuo. To the resulting red oil was added $\mathrm{MeOH}(50 \mathrm{~mL})$ and excess $\mathrm{KPF}_{6}$ $(1.3 \mathrm{~g}, 7.1 \mathrm{mmol})$. After $1 \mathrm{~h}$ of stirring at room temperature, evaporation of the solvent afforded a brown solid that was subsequently extracted with $\mathrm{CH}_{2} \mathrm{Cl}_{2}(3 \times 70 \mathrm{~mL})$, filtered to remove impurities and excess inorganic salts, and concentrated in vacuo to ca. $10 \mathrm{~mL}$. Addition of $\mathrm{Et}_{2} \mathrm{O}(60 \mathrm{~mL})$ induced precipitation of $1.7 \mathrm{~g}(72 \%)$ of brown product $\left([\alpha]_{D} 20=7.6\right.$ $\left.\left(\mathrm{CH}_{2} \mathrm{Cl}_{2}, \mathrm{C}=0.1\right)\right)$. ${ }^{1} \mathrm{H} \mathrm{NMR}\left(250 \mathrm{MHz} \mathrm{CDCl}_{3}\right): \delta 6.01(\mathrm{~m}$, $4 \mathrm{H}, \mathrm{Ar}), 5.32\left(\mathrm{~s}, 1 \mathrm{H}, \mathrm{C}_{5} \mathrm{H}_{4}\right), 5.22\left(\mathrm{~m}, 3 \mathrm{H}, \mathrm{C}_{5} \mathrm{H}_{4}\right), 3.51(\mathrm{q}, 1 \mathrm{H}$, 3) $(\mathrm{H}, \mathrm{H})=6.8, \mathrm{CHMe}), 2.68\left(q, 1 \mathrm{H}, \mathrm{CHMe}_{2}, 3 \mathrm{~J}(\mathrm{H}, \mathrm{H})=6.8\right)$, $2.32(\mathrm{~m}, 3 \mathrm{H}, \mathrm{Me}), 2.02$ (s, 3H, Me), $1.69(\mathrm{~m}, 3 \mathrm{H}, \mathrm{NMe}), 1.24$ $\left(\mathrm{d}, 6 \mathrm{H}, \mathrm{Me}_{2} \mathrm{CH},{ }^{3} \mathrm{~J}(\mathrm{H}, \mathrm{H})=6.8\right), 1.91-0.75(\mathrm{~m}, 11 \mathrm{H}, \mathrm{Cy}) .{ }^{13} \mathrm{C}$ NMR $\left(63 \mathrm{MHz}^{\mathrm{C}} \mathrm{CDCl}_{3}\right): \delta 136.0,117.6,87.1,86.8,84.5,84.4$, 80.7 ( $\mathrm{C}_{5} \mathrm{H}_{4}$ and $\mathrm{Ar}$ ), 59.8, 55.9 (CHMeN), 42.0 (NMe), 32.0, 31.0, 30.7, 29.9, 26.6, 26.5 (Cy), 23.4 ( $\left.\mathrm{CHMe}_{2}\right), 19.7$ ( $\left.\mathrm{CHMe}_{2}\right), 16.4$, 13.5 (CHMeN). MS (FAB) (m/e) $468\left(\mathrm{M}^{+}, 100 \%\right)$. Anal. Calcd for $\mathrm{C}_{26} \mathrm{H}_{40} \mathrm{NF}_{6} \mathrm{PRu} \cdot \mathrm{CH}_{2} \mathrm{Cl}_{2}: \mathrm{C}, 46.49 ; \mathrm{H}, 6.07 ; \mathrm{N}, 2.01$. Found: C, 46.74; $\mathrm{H}, 6.03 ; \mathrm{N}, 2.00$.

(S,R)-Cp*RuC ${ }_{5} \mathrm{H}_{4} \mathbf{C H}(\mathrm{Me}) \mathbf{N}(\mathrm{Me}) \mathrm{CH}(\mathrm{Me}) \mathrm{Cy}$ ((S,R)-6). To a solution of $\mathrm{LiC}_{5} \mathrm{H}_{4} \mathrm{CH}(\mathrm{Me}) \mathrm{N}(\mathrm{Me}) \mathrm{CH}(\mathrm{Me}) \mathrm{Cy}$ in ca. $30 \mathrm{~mL}$ of THF (prepared from $4.4 \mathrm{~g} \mathrm{(20} \mathrm{mmol)} \mathrm{of} \mathrm{(R)-} \mathrm{C}_{5} \mathrm{H}_{4}=\mathrm{CHN}(\mathrm{Me})$ $\mathrm{CH}(\mathrm{Me}) \mathrm{Cy}$ and $13 \mathrm{~mL}$ of $1.6 \mathrm{M} \mathrm{MeLi}(21 \mathrm{mmol})$ at $\left.0{ }^{\circ} \mathrm{C}\right)$ was added $\left[\mathrm{Cp} * \mathrm{Ru}\left(\mu^{3}-\mathrm{Cl}\right)\right]_{4}(5.0 \mathrm{~g}, 4.6 \mathrm{mmol})$. The resulting darkbrown solution was stirred for $30 \mathrm{~min}$. Water $(150 \mathrm{~mL})$ was added and the water layer extracted with hexane $(3 \times 200$ $\mathrm{mL}$ ). The combined extracts were dried over $\mathrm{MgSO}_{4}$ followed by removal of the solvent in vacuo. The residual brown oil was purified by chromatography on silica using hexane (containing ca. $5 \%$ of $\mathrm{Et}_{3} \mathrm{~N}$ ). Yield: $8.0 \mathrm{~g}(93 \%)$ of dark oil. ${ }^{1} \mathrm{H}$ NMR $\left(250 \mathrm{MHz}_{2} \mathrm{CDCl}_{3}\right): \delta 4.1\left(\mathrm{~m}, 4 \mathrm{H}, \mathrm{C}_{5} \mathrm{H}_{4}\right), 3.35$ and 2.38 (both q, $2 \times 1 \mathrm{H}, \mathrm{CH}(\mathrm{Me}) \mathrm{N}), 2.1$ (s, 3H, NMe), $1.9(\mathrm{~s}, 15 \mathrm{H}$, $\mathrm{C}_{5} \mathrm{Me}_{5}$ ), 1.17 and 0.75 (both $\mathrm{d}, 2 \times 3 \mathrm{H}, \mathrm{CHMeN}$ ). ${ }^{13} \mathrm{C} \mathrm{NMR}$ $\left(63 \mathrm{MHz}, \mathrm{CDCl}_{3}\right.$ ): $\delta 93.4$ (ipso-C of $\mathrm{C}_{5} \mathrm{H}_{4}$ ), 84.4 (ipso-C of $\left.\mathrm{C}_{5} \mathrm{Me}_{5}\right), 73.4,72.6,71.8,70.9\left(\mathrm{C}_{5} \mathrm{H}_{4}\right), 58.4(\mathrm{CpCH}), 56.5$ (CpCHMeNMeCH), 42.2 (NMe), 31.1-26.7 (Cy), 15.4 and 13.4 (both $\mathrm{CHMeN}$ ), $11.8\left(\mathrm{C}_{5} \mathrm{Me}_{5}\right)$. Anal. Calcd for $\mathrm{C}_{26} \mathrm{H}_{41} \mathrm{NRu}$ : C, 66.63; H, 8.82; N, 2.99. Found: C, 66.79; H, 8.63; N, 2.88.

(S)-Cp*R uC ${ }_{5} \mathrm{H}_{4} \mathbf{C H}(\mathrm{Me}) \mathrm{NMe}_{2}$ ((S)-7). To a cooled (ca. -10 $\left.{ }^{\circ} \mathrm{C}\right)$ dark solution of $(\mathrm{S}, \mathrm{R})-\mathbf{6}(13.8 \mathrm{~g}, 29.3 \mathrm{mmol})$ in $\mathrm{HNMe}_{2}(25$ $\mathrm{mL}$ ) was slowly added $45 \mathrm{~mL}$ of $\mathrm{AcOH}$. The resulting solid was heated for $30 \mathrm{~min}$ at $60^{\circ} \mathrm{C}$, giving a clear dark solution. Water (ca. $100 \mathrm{~mL}$ ) was added and the $\mathrm{pH}$ adjusted to ca. 10 by careful addition of $\mathrm{NaOH}$. Extraction with hexane $(3 \times 200$ $\mathrm{mL}$ ), followed by drying of the combined extracts over $\mathrm{MgSO}_{4}$ and removal of the solvent in vacuo, gave a dark oil that contained the product together with $\mathrm{HN}(\mathrm{Me}) \mathrm{CH}(\mathrm{Me}) \mathrm{Cy}$. This sec-amine was distilled off $\left(100{ }^{\circ} \mathrm{C}, 0.1\right.$ Torr) leaving the product as a brown oil; yield $10.2 \mathrm{~g}(93 \%)$. ${ }^{1} \mathrm{H}$ NMR $(250 \mathrm{MHz}$, $\left.\mathrm{CDCl}_{3}\right): \delta 4.1\left(\mathrm{~m}, 4 \mathrm{H}, \mathrm{C}_{5} \mathrm{H}_{4}\right), 3.24(\mathrm{q}, 1 \mathrm{H}, \mathrm{CHMe}), 2.1(\mathrm{~s}, 6 \mathrm{H}$, $\left.\mathrm{NMe}_{2}\right), 1.9\left(\mathrm{~s}, 15 \mathrm{H}, \mathrm{C}_{5} \mathrm{Me}_{5}\right), 1.23(\mathrm{~d}, 3 \mathrm{H}, \mathrm{CHMe}) .{ }^{13} \mathrm{C} \mathrm{NMR}(63$ $\mathrm{MHz}_{2} \mathrm{CDCl}_{3}$ ): $\delta 89.5$ (ipso-C of $\mathrm{C}_{5} \mathrm{H}_{4}$ ), 84.1 (ipso-C of $\mathrm{C}_{5} \mathrm{Me}_{5}$ ), 73.2, 72.2, 71.8, $70.4\left(\mathrm{C}_{5} \mathrm{H}_{4}\right), 57.5(\mathrm{CpCH}), 40.4\left(\mathrm{NMe}_{2}\right), 14.6$ (CHMeN), $11.6\left(\mathrm{C}_{5} \mathrm{Me}_{5}\right)$. Anal. Calcd for $\mathrm{C}_{19} \mathrm{H}_{29} \mathrm{NRu}$ : C, 61.26; $H$, 7.85: N, 3.76. Found: C, 61.74; H, 7.68; N, 3.40.

(S)-(R)-Cp*RuC ${ }_{5} \mathrm{H}_{3} \mathrm{CH}(\mathrm{Me}) \mathrm{NMe}_{2} \mathrm{PPh}_{2}-\mathbf{2}$ ((S)-(R)-8). A solution of (S)-7 (10.2 g, $27.4 \mathrm{mmol})$ and BuLi (19 mL $1.6 \mathrm{M}$ (30.4 mmol in hexane) in $\mathrm{Et}_{2} \mathrm{O}(50 \mathrm{~mL})$ was stirred for 2 days. Subsequently, $\mathrm{PPh}_{2} \mathrm{Cl}(6.0 \mathrm{~mL}, 32 \mathrm{mmol})$ was added and the resulting brown suspension was refluxed for $4 \mathrm{~h}$ followed by careful addition of saturated $\mathrm{NaHCO}_{3}$ (ca. $30 \mathrm{~mL}$ ). Extraction with toluene $(3 \times 100 \mathrm{~mL})$ followed by drying of the combined organic layers on $\mathrm{MgSO}_{4}$ and removal of the solvent in vacuo gave a reddish oil. This was subjected to flash chromatography over silica using hexane (containing ca. $5 \%$ of $\mathrm{Et}_{3} \mathrm{~N}$ ) in order to elute impurities followed by elution of the product with THF. Finally, the product was purified by flash chromatography over $\mathrm{Al}_{2} \mathrm{O}_{3}$ using toluene (containing ca. $5 \%$ of $\mathrm{Et}_{3} \mathrm{~N}$ ) affording 10.2 $\mathrm{g}(67 \%)$ of product. Crystallization from ethanol gave $1.7 \mathrm{~g}$ of crystalline, pale yellow, almost racemic product $\left([\alpha]_{\mathrm{D}}{ }^{20}=14\right.$ $\left.\left(\mathrm{CHCl}_{3}, \mathrm{C}=1.0\right)\right)$ while removal of the solvent from the mother liquor in vacuo left $8.5 \mathrm{~g}$ of almost optically pure compound as a red oil $\left([\alpha]_{D}{ }^{20}=248\left(\mathrm{CHCl}_{3}, \mathrm{C}=0.44\right)\right)$. ${ }^{1} \mathrm{H}$ NMR $(250$ $\left.\mathrm{MHz}_{2} \mathrm{CDCl}_{3}\right): \delta 7.62\left(\mathrm{~m}, 2 \mathrm{H}, \mathrm{PPh}_{2}\right), 7.27\left(\mathrm{~m}, 8 \mathrm{H}, \mathrm{PPh}_{2}\right), 4.23$ $\left(\mathrm{m}, 3 \mathrm{H}, \mathrm{C}_{5} \mathrm{H}_{3}\right), 3.65\left(\mathrm{dq}, 1 \mathrm{H}, \mathrm{CHMeN}, 3 \mathrm{~J}(\mathrm{H}, \mathrm{H})=6.5,{ }^{4} \mathrm{~J}(\mathrm{P}, \mathrm{H})\right.$ $=1.7), 1.90\left(\mathrm{~s}, 15 \mathrm{H}, \mathrm{C}_{5} \mathrm{Me}_{5}\right), 1.78\left(\mathrm{~s}, 6 \mathrm{H}, \mathrm{NMe}_{2}\right), 0.98(\mathrm{~d}, 3 \mathrm{H}$, $\mathrm{CH}(\mathrm{Me}) \mathrm{N}$ ). ${ }^{13} \mathrm{C} \mathrm{NMR}\left(63 \mathrm{MHz} \mathrm{CDCl}_{3}\right.$ ): $\delta$ 135.0-126.8 (non quartenary $\mathrm{C}$ of $\left.\mathrm{PPh}_{2}\right), 85.1\left(\mathrm{C}_{5} \mathrm{Me}_{5}\right), 75.9,74.8,74.0$ (non quartenary $\mathrm{C}$ of $\left.\mathrm{C}_{5} \mathrm{H}_{3}\right), 56.1(\mathrm{CHMeN}), 38.4\left(\mathrm{NMe}_{2}\right), 11.5$ $\left(\mathrm{C}_{5} \mathrm{Me}_{5}\right), 7.2(\mathrm{CHMeN})$. ${ }^{31} \mathrm{P} \mathrm{NMR}\left(101 \mathrm{MHz}, \mathrm{CDCl}_{3}\right): \delta-24.6$ $\left(\mathrm{s}, \mathrm{PPh}_{2}\right)$. Anal. Calcd for $\mathrm{C}_{31} \mathrm{H}_{38} \mathrm{NPRu}$ : C, 66.88; $\mathrm{H}, 6.88$ : $\mathrm{N}, 2.52$. Found: C, 66.95; $\mathrm{H}, 6.88 ; \mathrm{N}, 2.47$.

(S)-(R)-Cp*R uC ${ }_{5} \mathrm{H}_{3} \mathrm{CH}(\mathrm{Me}) \mathrm{PC}_{2} \mathrm{PPh}_{2}-2$ ((S)-(R)-9). A solution of (S)-(R)-8 $(0.95 \mathrm{~g}, 1.7 \mathrm{mmol})$ and $\mathrm{HPCy}_{2}(0.38 \mathrm{~mL}$, $1.9 \mathrm{mmol})$ in $\mathrm{AcOH}(35 \mathrm{~mL})$ was stirred at $80^{\circ} \mathrm{C}$ for $2 \mathrm{~h}$. The solvent was removed in vacuo and the sticky residue subjected to flash chromatography on $\mathrm{Al}_{2} \mathrm{O}_{3}$ using hexane/toluene $(3: 1$, containing $5 \% \mathrm{Et}_{3} \mathrm{~N}$ ) as eluent. The product was obtained analytically pure after crystallization from a minimum of hot $\mathrm{EtOH}$; yield $0.75 \mathrm{~g}(62 \%)$ of pale yellow crystals $\left([\alpha]_{\mathrm{D}}{ }^{20}=253\right.$ $\left(\mathrm{CHCl}_{3}, \mathrm{C}=1.1\right)$ ). Note: the racemic compound (prepared via the same method from racemic $\mathrm{Cp} * \mathrm{RuC}_{5} \mathrm{H}_{3} \mathrm{CH}(\mathrm{Me}) \mathrm{NM} \mathrm{e}_{2} \mathrm{PPh}_{2^{-}}$ 2) can be separated on a Daicel Chiracel OD-H column (hexane/2-propanol $=99.5: 0.5$, flow $=1.0 \mathrm{~mL} \cdot \mathrm{min}^{-1}$ ) with $\mathrm{R}_{\mathrm{t}}$ $(\mathrm{R})-(\mathrm{S})=3.34 \mathrm{~min}$ and $\mathrm{R}_{\mathrm{t}}(\mathrm{S})-(\mathrm{R})=3.44 \mathrm{~min}$. ${ }^{1 \mathrm{H}} \mathrm{NMR}(250$ $\left.\mathrm{MHz} \mathrm{CDCl}_{3}\right): \delta 7.63\left(\mathrm{~m}, 2 \mathrm{H}, \mathrm{PPh}_{2}\right), 7.25\left(\mathrm{~m}, 8 \mathrm{H}, \mathrm{PPh}_{2}\right), 4.44$, $4.13\left(\mathrm{~m}, 3 \mathrm{H}, \mathrm{C}_{5} \mathrm{H}_{3}\right), 2.79(\mathrm{dq}, 1 \mathrm{H}, \mathrm{CHMeP}, 3 \mathrm{j}(\mathrm{H}, \mathrm{H})=5.4$, 
$J(P, H)=2.2 \mathrm{~Hz}), 1.73\left(\mathrm{~s}, 15 \mathrm{H}, \mathrm{C}_{5} \mathrm{Me}_{5}\right), 1.38(\mathrm{dd}, 3 \mathrm{H}, \mathrm{CHMeP}$, 3) $(\mathrm{H}, \mathrm{H})=5.7,3 \mathrm{~J}(\mathrm{H}, \mathrm{P})=7.1), 1.8-1.3(\mathrm{~m}, 22 \mathrm{H}, \mathrm{Cy}) .{ }^{13} \mathrm{C} N M R$ $\left(63 \mathrm{MHz} \mathrm{CDCl}_{3}\right): \delta$ 135.7-126.7 (nonquartenary $\mathrm{C}$ of $\mathrm{PPh}_{2}$ ), $85.0\left(\mathrm{C}_{5} \mathrm{Me}_{5}\right), 75.6,74.5,74.1$ (nonquartenary $\mathrm{C}$ of $\mathrm{C}_{5} \mathrm{H}_{5}$ ), 32.7$24.7\left(\mathrm{PCy}_{2}\right), 18.2$ (CHMeP), $11.6\left(\mathrm{C}_{5} \mathrm{Me}_{5}\right) .{ }^{31} \mathrm{P} \mathrm{NMR}(101 \mathrm{MHz}$, $\left.\mathrm{CDCl}_{3}\right): \delta-26.3\left(\mathrm{~d}, \mathrm{PPh}_{2}, 4 \mathrm{~J}(\mathrm{P}, \mathrm{P})=36 \mathrm{~Hz}\right), 11.5\left(\mathrm{~d}, \mathrm{PCy}_{2}\right.$, 4J $(P, P)=36 \mathrm{~Hz}$ ). Anal. Calcd for $\mathrm{C}_{41} \mathrm{H}_{54} \mathrm{P}{ }_{2} \mathrm{Ru}$ : C, 69.37; $\mathrm{H}$, 7.67. Found: $C, 69.62 ; \mathrm{H}, 7.62$.

(S)-(R)-Cp*RuC ${ }_{5} \mathrm{H}_{3} \mathrm{CH}(\mathrm{Me}) \mathrm{PC}_{8} \mathrm{H}_{14} \mathrm{PPh}_{2}-2$ ((S)-(R)-10). The procedure is the same as that for (S)-(R)-9 except that (S)-(R)-8 (0.40 g, $0.72 \mathrm{mmol})$ and $\mathrm{HPC}_{8} \mathrm{H}_{14}(1.28 \mathrm{~g}, 8.8 \mathrm{mmol}$, 2:1 mixture of [3.3.1] and [4.2.1] isomers) reacted to give 0.19 $\mathrm{g}(40 \%)$ of pale yellow crystalline product $\left([\alpha]_{\mathrm{D}}{ }^{20}=+182\right.$, $\left(\mathrm{CHCl}_{3}, \mathrm{C}=0.70\right)$ ). Note: the racemic compound (prepared via the same method from racemic $\mathrm{Cp}^{*} \mathrm{RuC}_{5} \mathrm{H}_{3} \mathrm{CH}(\mathrm{Me}) \mathrm{NMe}_{2}-$ $\mathrm{PPh}_{2}-2$ ) can be separated on a Daicel Chiracel OD-H column (hexane/2-propanol $=99.0: 1.0$, flow $=0.5 \mathrm{~mL} \cdot \mathrm{min}^{-1}$ ) with $\mathrm{R}_{\mathrm{t}}$ (R)-(S) $=7.19 \mathrm{~min}$ and $\mathrm{R}_{\mathrm{t}}(\mathrm{S})-(\mathrm{R})=7.44 \mathrm{~min} .{ }^{1} \mathrm{H} N M R(250$ $\left.\mathrm{MHz}, \mathrm{CDCl}_{3}\right): \delta 7.58\left(\mathrm{~m}, 2 \mathrm{H}, \mathrm{PPh}_{2}\right), 7.26\left(\mathrm{~m}, 8 \mathrm{H}, \mathrm{PPh}_{2}\right), 4.65$, 4.10, and $4.06\left(\mathrm{~m}, 3 \mathrm{H}, \mathrm{C}_{5} \mathrm{H}_{3}\right), 2.80(\mathrm{q}, 1 \mathrm{H}, \mathrm{CHMeP}, 3 \mathrm{~J}(\mathrm{H}, \mathrm{H})=$ 6.2), $1.76\left(\mathrm{~s}, 15 \mathrm{H}, \mathrm{C}_{5} \mathrm{Me}_{5}\right), 2.0-1.0\left(\mathrm{~m}, 14 \mathrm{H}, \mathrm{C}_{8} \mathrm{H}_{14}\right), 1.40$ (dd, $3 \mathrm{H}, \mathrm{CHMeP}, 3 \mathrm{H}(\mathrm{H}, \mathrm{H})=6.2$, 3 $(\mathrm{H}, \mathrm{P})=13) .{ }^{13} \mathrm{C} \mathrm{NMR}(63 \mathrm{MHz}$, $\mathrm{CDCl}_{3}$ ): $\delta$ 140.8-127.8 (nonquartenary $\mathrm{C}$ of $\mathrm{PPh}_{2}$ ), 85.7 $\left(\mathrm{C}_{5} \mathrm{Me}_{5}\right), 75.2,75.4,73.8$ (non quartenary $\mathrm{C}$ of $\mathrm{C}_{5} \mathrm{H}_{3}$ ), 32.4$23.3\left(\mathrm{PC}_{8} \mathrm{H}_{14}\right), 21.5(\mathrm{CHMeP}), 12.2\left(\mathrm{C}_{5} \mathrm{Me}_{5}\right)$. ${ }^{31} \mathrm{P} \mathrm{NMR}$ (101 $\left.\mathrm{MHz}_{2} \mathrm{CDCl}_{3}\right): \delta-25.6\left(\mathrm{~s}, \mathrm{PPh}_{2}\right),-17.8\left(\mathrm{~s}, \mathrm{PCy}_{2}\right)$. Anal. Calcd for $\mathrm{C}_{37} \mathrm{H}_{46} \mathrm{P}_{2} \mathrm{Ru}$ : C, 67.97; $\mathrm{H}, 7.09$. Found: $\mathrm{C}, 67.92 ; \mathrm{H}, 6.83$.

Racemic (S*)-(R*)-Cp*RuC ${ }_{5} \mathrm{H}_{3} \mathrm{CH}(\mathrm{Me})\left\{\mathrm{N}_{2} \mathrm{C}_{3} \mathrm{HMe}_{2}-3,5\right)-$

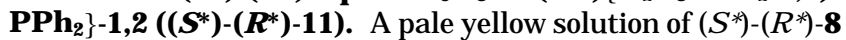
$(0.60 \mathrm{~g}, 1.1 \mathrm{mmol})$ and 3,5-dimethylpyrazole $(1.60 \mathrm{~g}, 16.6 \mathrm{mmol})$ in $5 \mathrm{~mL}$ of $\mathrm{AcOH}$ was heated at $60^{\circ} \mathrm{C}$ for $30 \mathrm{~min}$. Water $(60$ $\mathrm{mL}$ ) was added, and the resulting suspension was made basic by careful addition of $\mathrm{NaOH}$, followed by extraction with hexane $(100 \mathrm{~mL})$. The hexane extract was dried over $\mathrm{MgSO}_{4}$ and the solvent removed in vacuo, leaving a crude product that was crystallized from ca. $50 \mathrm{~mL}$ of hot $\mathrm{EtOH} / \mathrm{H}_{2} \mathrm{O}(4: 1)$ to give $0.32 \mathrm{~g}(49 \%)$ of pale yellow product.

(S)-(R)-Cp*RuC $\left.{ }_{5} \mathrm{H}_{3} \mathrm{CH}(\mathrm{Me})\left\{\mathrm{N}_{2} \mathrm{C}_{3} \mathrm{HMe}_{2}-3,5\right) \mathrm{PPh}_{2}\right\}-1,2$ ((S)(R)-11). The procedure is the same as above, except that (S)(R)-8 (0.65 g, $1.2 \mathrm{mmol}$ ) and 3,5-dimethylpyrazole (0.90 g, 9.3 $\mathrm{mmol}$ ) reacted to give $0.80 \mathrm{~g}$ of crude product, contaminated by excess dimethyl pyrazole. The compound could be obtained analytically pure in ca. $10 \%$ yield by repeated crystallization from EtOH $/ \mathrm{H}_{2} \mathrm{O}$. ${ }^{1} \mathrm{H} \mathrm{NMR}\left(250 \mathrm{MHz}, \mathrm{CDCl}_{3}\right): \delta 7.51(\mathrm{~m}, 2 \mathrm{H}$, $\left.\mathrm{PPh}_{2}\right), 7.25\left(\mathrm{~m}, 3 \mathrm{H}, \mathrm{PPh}_{2}\right), 6.98\left(\mathrm{q}, 3 \mathrm{H}, \mathrm{PPh}_{2}\right), 6.85(\mathrm{t}, 2 \mathrm{H}$, $\left.\mathrm{PPh}_{2}\right), 5.14(\mathrm{dq}, 1 \mathrm{H}, \mathrm{CHMeN}, 3 \mathrm{~J}(\mathrm{H}, \mathrm{H})=6.8,4 \mathrm{~J}(\mathrm{P}, \mathrm{H})=1.9)$, 4.99 (s, $\left.1 \mathrm{H}, \mathrm{N}_{2} \mathrm{C}_{3} \mathrm{H}\right), 4.73,4.30$, and $4.01\left(\mathrm{~m}, 3 \mathrm{H}, \mathrm{C}_{5} \mathrm{H}_{3}\right), 2.12$, $1.93\left(\mathrm{~s}, 2 \times 3 \mathrm{H}, \mathrm{N}_{2} \mathrm{C}_{3} \mathrm{HMe}_{2}\right), 1.81\left(\mathrm{~s}, 15 \mathrm{H}, \mathrm{C}_{5} \mathrm{Me}_{5}\right), 1.59$ (d, 3H, $\left.\mathrm{CHMeN},{ }^{3} \mathrm{H}(\mathrm{H}, \mathrm{H})=6.9\right) .{ }^{13} \mathrm{C} \mathrm{NMR}\left(63 \mathrm{MHz} \mathrm{CDCl}_{3}\right): \delta 135.5-$ 126.8 (nonquartenary $\mathrm{C}$ of $\mathrm{PPh}_{2}$ ), $104.2\left(\mathrm{p}-\mathrm{C}\right.$ of $\mathrm{C}_{3} \mathrm{~N}_{2}$ ), 85.5 $\left(\mathrm{C}_{5} \mathrm{Me}_{5}\right), 76.0,75.4$ (nonquartenary $\mathrm{C}$ of $\left.\mathrm{C}_{5} \mathrm{H}_{3}\right), 51.3$ (d, $\mathrm{CHMeN}$, 3ै $(\mathrm{P}, \mathrm{H})=7), 20.0,13.7\left(\mathrm{~N}_{2} \mathrm{C}_{3} \mathrm{HMe}_{2}\right), 11.4(\mathrm{CHMeP}$, 4J $(\mathrm{P}, \mathrm{H})=9), 11.7\left(\mathrm{C}_{5} \mathrm{Me}_{5}\right) .{ }^{31} \mathrm{P} N M R\left(101 \mathrm{MHz}, \mathrm{CDCl}_{3}\right): \delta$ $-26.5\left(\mathrm{~s}, \mathrm{PPh}_{2}\right) .\left([\alpha]_{\mathrm{D}}{ }^{20}=+202\left(\mathrm{CHCl}_{3}, \mathrm{C}=0.19\right)\right)$. Anal. Calcd for $\mathrm{C}_{34} \mathrm{H}_{39} \mathrm{~N}_{2} \mathrm{PRu}$ : C, 67.20; $\mathrm{H}, 6.47 ; \mathrm{N}, 4.61$. Found: $\mathrm{C}, 67.24$; $\mathrm{H}, 6.46 ; \mathrm{N}, 4.45$.

Racemic (S*)-(R*)-[(Cp*FeC ${ }_{5} \mathrm{H}_{3}\left(\mathrm{CH}(\mathrm{Me}) \mathrm{PCy}_{2}\right)\left(\mathrm{PPh}_{2}\right)-$ 1,2)Pd $\left.\left(\eta^{3}-C_{3} H_{5}\right)\right]^{+}[\mathrm{OTf}]^{-}\left(\left(S^{*}\right)-\left(R^{*}\right)-12\right)$. To a stirred solution of $\left[\mathrm{PdCl}\left(\eta^{3}-\mathrm{C}_{3} \mathrm{H}_{5}\right)\right]_{2}(52 \mathrm{mg}, 0.14 \mathrm{mmol})$ and $\left(\mathrm{S}^{*}\right)-\left(\mathrm{R}^{*}\right)-$ Cp*FeC ${ }_{5} \mathrm{H}_{3}\left(\mathrm{CH}(\mathrm{Me}) \mathrm{PCy}_{2}\right)\left(\mathrm{PPh}_{2}\right)-1,2$ (199 mg, $\left.0.30 \mathrm{mmol}\right)$ in $\mathrm{CH}_{2} \mathrm{Cl}_{2}(10 \mathrm{~mL})$ was added $\mathrm{Ag}_{2}\left[\mathrm{CF}_{3} \mathrm{SO}_{3}\right](77 \mathrm{mg}, 0.30 \mathrm{mmol})$, dissolved in $1 \mathrm{~mL}$ of $\mathrm{MeOH}$. After $1 \mathrm{~h}$, the resulting brown suspension was filtered over Celite and the filtrate evaporated in vacuo. The orange spongy residue was dissolved in $10 \mathrm{~mL}$ of $\mathrm{CH}_{2} \mathrm{Cl}_{2}$ and layered with $50 \mathrm{~mL}$ of hexane. From this system, $210 \mathrm{mg}(70 \%)$ of crystalline red product could be obtained overnight. ${ }^{31} \mathrm{P} \mathrm{NMR}\left(101 \mathrm{MHz}^{\mathrm{C}} \mathrm{CDCl}_{3}\right)$ : 2 isomers in approximate 1:2 ratio; minor isomer, $\delta 61.1\left(\mathrm{~d}, \mathrm{PPh}_{2}, 4 \mathrm{~J}(\mathrm{P}, \mathrm{P})\right.$ $=49 \mathrm{~Hz}), 17.0(\mathrm{~d}, \mathrm{PCy}, 4 \mathrm{~J}(\mathrm{P}, \mathrm{P})=49 \mathrm{~Hz})$; major isomer, $\delta 58.7$ $\left(d, P \mathrm{Ph}_{2}, 4 \mathrm{~J}(\mathrm{P}, \mathrm{P})=46 \mathrm{~Hz}\right), 15.0\left(\mathrm{~d}, \mathrm{PCy}_{2}\right.$, u $\left.(\mathrm{P}, \mathrm{P})=46 \mathrm{~Hz}\right)$. The ${ }^{1} \mathrm{H}$ and ${ }^{13} \mathrm{C} N M R$ spectra were poorly resolved indicating fluxionality in solution. Anal. Calcd for $\mathrm{C}_{45} \mathrm{H}_{59} \mathrm{O}_{3} \mathrm{~F}_{3} \mathrm{P}_{2} \mathrm{FePdS}$. $1 / 2 \mathrm{CH}_{2} \mathrm{Cl}_{2}$ : C, 54.48; $\mathrm{H}, 6.03$. Found: $\mathrm{C}, 54.24 ; \mathrm{H}, 5.91$.

(S*)-(R*)-[(Cp*RuC $\left.{ }_{5} \mathrm{H}_{3}\left(\mathrm{CH}(\mathrm{Me}) \mathrm{PCy}_{2}\right)\left(\mathrm{PPh}_{2}\right)-1,2\right) \mathrm{Pd}\left(\eta^{3}\right.$ $\left.\left.\mathbf{C}_{3} \mathbf{H}_{5}\right)\right]^{+}$[OTf] $\left.{ }^{-}\left(\mathbf{S}^{*}\right)-\left(\mathbf{R}^{*}\right)-13\right)$. The procedure is the same as that for $\left(\mathrm{S}^{*}\right)-\left(\mathrm{R}^{*}\right)-12$ except that $\left[\mathrm{PdCl}\left(\eta^{3}-\mathrm{C}_{3} \mathrm{H}_{5}\right)\right]_{2}(24 \mathrm{mg}, 0.07$ $\mathrm{mmol}$ ), (S*)-(R*)-9 (100 mg, $0.14 \mathrm{mmol})$ in $\mathrm{CH}_{2} \mathrm{Cl}_{2}(5 \mathrm{~mL})$, and $\mathrm{Ag}\left[\mathrm{CF}_{3} \mathrm{SO}_{3}\right]$ (36 mg, $0.14 \mathrm{mmol}$ ) reacted to give ca. $70 \mathrm{mg}(50 \%)$ of crystalline product. ${ }^{31} \mathrm{P} \mathrm{NMR}\left(101 \mathrm{M} \mathrm{Hz} \mathrm{CDCl}_{3}\right)$ : 2 isomers in approximate 2:3 ratio; minor isomer, $\delta 64.9\left(\mathrm{~d}, \mathrm{PPh}_{2}, 4 \mathrm{~J}(\mathrm{P}, \mathrm{P})\right.$ $=47 \mathrm{~Hz}), 14.4\left(\mathrm{~d}, \mathrm{PCy},{ }_{2}{ }^{4} \mathrm{f}(\mathrm{P}, \mathrm{P})=47 \mathrm{~Hz}\right)$; major isomer, $\delta 67.8$

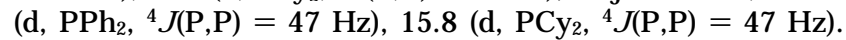
Anal. Calcd for $\mathrm{C}_{45} \mathrm{H}_{59} \mathrm{O}_{3} \mathrm{~F}_{3} \mathrm{P}_{2} \mathrm{RuPdS}$ : C, 53.70; $\mathrm{H}, 5.91$. Found: C, 53.83; $\mathrm{H}, 6.09$.

X-Ray Crystallographic Studies of 5, 9, 10, 12, and 13. Selected crystallographic and relevant data collection parameters for 9, 12, and $\mathbf{1 3}$ are listed in Table 1. Data were measured with variable scan speed to ensure constant statistical precision on the collected intensities. One standard reflection was measured every 120 reflections; no significant variation was detected.

The structures were solved either by direct $(5,10,12,13)$ or Patterson (9) methods and refined by full-matrix leastsquares using anisotropic displacement parameters for all nonhydrogen atoms. The contribution of the hydrogen atoms in their idealized position (riding model with fixed isotropic $U=$ $0.080 \AA^{2}$ ) was taken into account but not refined. All calculations were carried out by using the Siemens SHELXTL PLUS system.

Acknowledgment. This research was in part supported by the Swiss National Science Foundation, program $\mathrm{CH}$ iral 2 (postdoctoral grants to H.C.L.A. and J.S.).

Supporting Information Available: Tables of crystal data and refinement details, complete atomic coordinates and $U$ values, complete bond distances and angles, and anisotropic displacement coefficients for the non-carbon atoms for compounds 5, 9, 10, 12, and 13 and ORTEP views and atomnumbering schemes for compounds $\mathbf{9}$ and $\mathbf{1 0}$ (F igures S1 and S2) (52 pages). Ordering information is given on any current masthead page.

\section{OM9508997}

